\title{
Simulation of Flood Event in Kelantan on December 2014 as Revealed by the HEC-HMS
}

\author{
Muhamad Zulhilmi Abdul Latif \\ 85 Jalan Jawi Jaya 2, Taman Jawi Jaya, 14200 Sg Jawi, SPS Pulau Pinang, MALAYSIA \\ muhamadzulhilmi17@gmail.com
}

\begin{abstract}
A devastating flood disaster occurred at Kuala Krai, Kelantan on December 2014. The flood disaster had given a significant destructive impact on the infrastructure and as a result, almost 1,600 homes were lost or destroyed. This extreme flood event killed 25 villages and forced 45,467 people in Kuala Krai, Kelantan to be evacuated from their homes. Continuous heavy rain for over three days from the $21^{\text {st }}$ to the $23^{\text {rd }}$ of December, 2014 was set a rainfall record of 1,295 mm, equivalent to the amount of rain usually seen in a span of 64 days. As a result, the water levels of three major rivers, the Sungai Galas in Dabong, the Sungai Lebir in Tualang and the Sungai Kelantan in Jambatan Gueillemard, rose above the dangerous water levels. It is essential to estimate the extent of flood inundation. The objective of this study is to simulate flood event in December 2014 by using HECHMS. The results show the peak discharges and inundations occurred approximately on the $25^{\text {th }}$ December $2014 ; 18,575.7 \mathrm{~m}^{3} / \mathrm{s}$ to be almost similar magnitude as reported by DID 2014 Flood Report. These findings led to the conclusion that the HEC-HMS model is useful as a flood analysis tool.
\end{abstract}

Keywords: Flood simulation, flood disaster, Kelantan Catchment and Kuala Krai.

\section{INTRODUCTION}

Malaysian witnessed an extraordinary natural phenomenon in December 2014. A massive flood is known as the yellow flood (Bah Kuning) that inundated much of Kelantan on December 23 ${ }^{\text {th }}, 2014$ (Bernama, 2015). Almost $80 \%$ of the building in Kuala Krai was drowned by floods in December 2014. In 2014, two extreme precipitation events were hit the Sungai Kelantan catchment between $15^{\text {th }}$ and $21^{\text {st }}$ December 2014 with daily rainfall between $100-300 \mathrm{~mm}$ while on $22^{\text {nd }}$ and $24^{\text {th }}$ December 2014 the daily rainfall up to $500 \mathrm{~mm}$. The consequent of these extreme rainfall events, a prolong and extreme flooding occurred during these periods that cause 25 deaths and around RM2.81 billion losses (Yusop, 2015) Sungai Kelantan contains the confluence of two major rivers there are Sungai Lebir and Sungai Galas. There are six sub-catchments in Sungai Kelantan namely Galas, Nenggiri, Pergau, Guillemard Bridge, Kuala Krai and Lebir. The length of Sungai Kelantan is about $248 \mathrm{~km}$ long starts at Banjaran Titiwangsa and end up in the South China Sea (Romali, et al. 2018). It inundates an area of 13,088 $\mathrm{km}^{2}$ and occupies more than $88 \%$ of the State of
Kelantan (Yusop, 2015). It flows $70 \mathrm{~km}$ northward trough one of most densely populated floodplains near the State Capital of Kota Bharu. Figure 1 shows the area of the study within the boundaries of this study are $+6^{\circ} 13^{\prime} 30^{\prime \prime},+4^{\circ} 31^{\prime} 0^{\prime \prime},+101^{\circ} 17^{\prime} 30^{\prime \prime}$ and $+102^{\circ} 42^{\prime} 0^{\prime \prime}$. Also, the entire catchment contains large areas of tropical forested mountains, lowland forest, and limestone hills.

A devastating flood disaster occurred in Kuala Krai, Kelantan in December 2014. The flood event showed a significant flood when river banks burst and caused prolong local inundation. Based on the DID report 2014, Gagau rainfall station was recorded the amount of rainfall received on 10 days duration are almost similar with $50 \%$ of annual rainfall. As a result, the total of estimated flood damage to infrastructure and buildings are loss almost RM 56,704,000. In order to minimize the losses around Kuala Krai area, it is important to know how large the impact of the disaster. Thus, this study aims to determine the discharge in Kelantan catchment due to flood event in December 2014. 


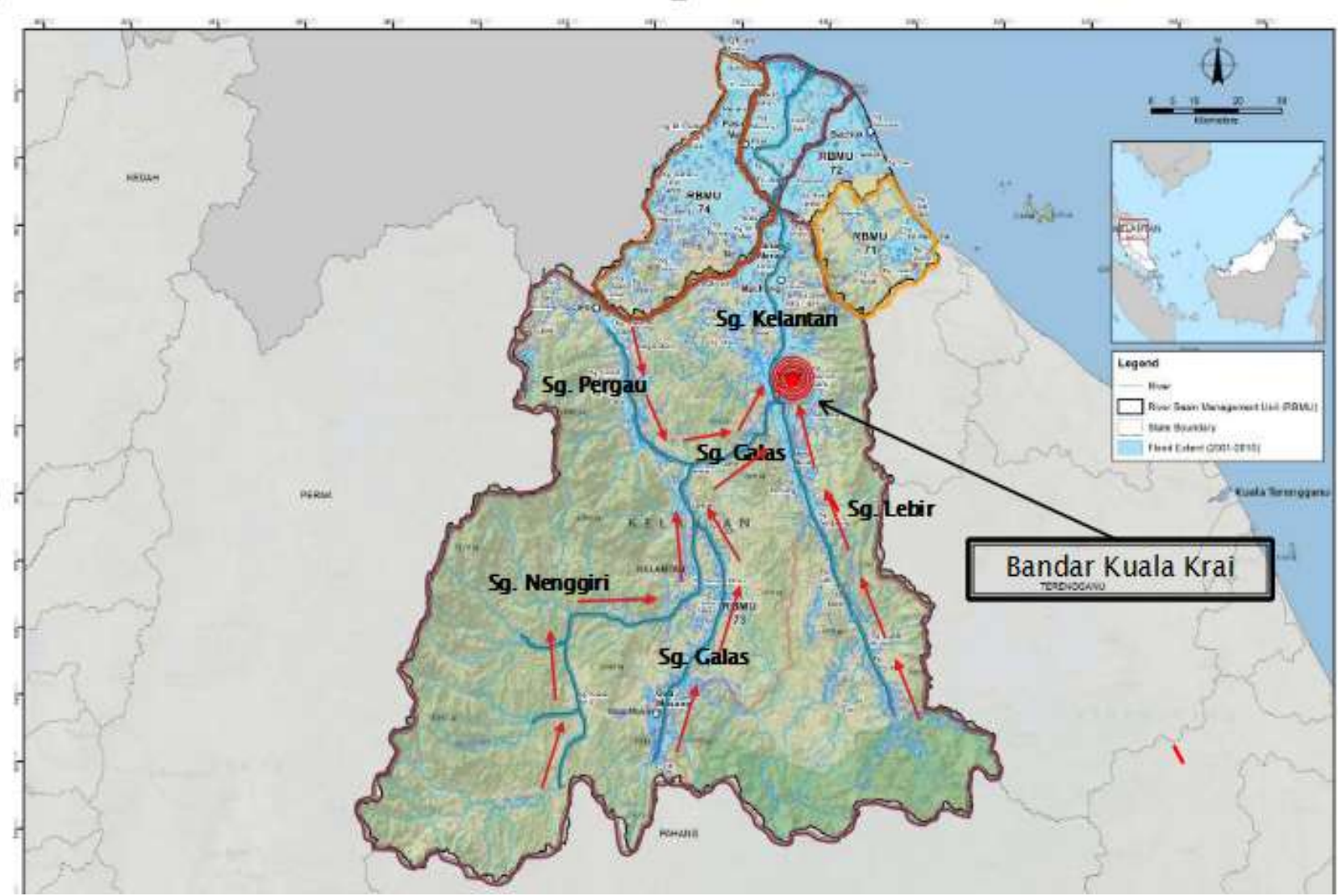

Figure 1. Area of Kelantan Catchment

\section{METHODOLOGY}

\subsection{Data Collection}

Data used in this study is secondary data that obtained from various institutions in Malaysia such as Department of Irrigation and Drainage (DID). Hydrological data which includes daily rainfall data from 21 rainfall stations in Kelantan catchment area that provided from DID Malaysia.

\subsection{Catchment Area}

The sub-catchment in this study are divided into three major catchments. The upstream of the basin is Lebir and Galas sub-catchments while in the downstream of the catchment is Sungai Kelantan sub-catchment. Figure 2 shows the sub-catchment in Kelantan and its rainfall stations in the catchment. The total area of the Kelantan's catchment is around 13,088 $\mathrm{km}^{2}$. While Galas sub-catchment around 7,917 $\mathrm{km}^{2}$ and Lebir subcatchment area around 3,296 $\mathrm{km}^{2}$.

\subsection{Rainfall Analysis}

The rainfall analysis is conducted based on the secondary data that provided from Department of Irrigation and Drainage Malaysia. There are 21 rainfall stations used and the rainfall station is divided by 3 based on the sub-catchment. The mean rainfall in December 2014 in Kelantan is analyzed by the Thiessen Polygon method. The result of the mean rainfall based on the 3 sub-catchment was used as an input data in HEC-HMS. 


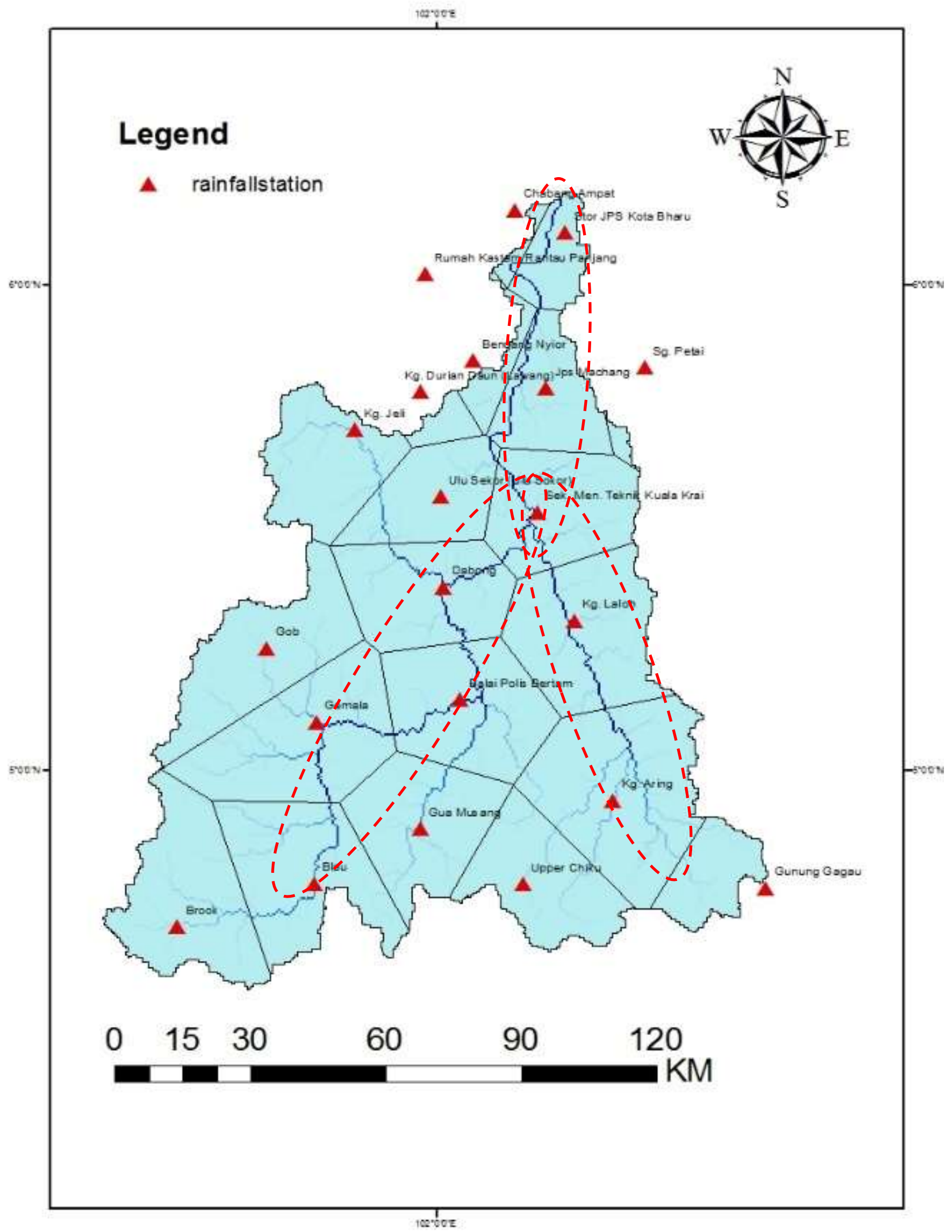

Figure 2. Catchment Area in Kelantan 


\subsection{HEC-HMS Modeling}

One way to identify the flood inundation impact due to heavy rainfall is approached through the hydraulichydrology modeling (Fang, et al., 2016). The input data needed in HEC-HMS are rainfall data and observed discharge data. Model and method used in this study are shown in Table 1. Figure 3 shows the layout of the Kelantan catchment needs to be drawn as an input in HEC-HMS. The result from the HEC-HMS is calibrated from the observed data that provided from Department of Irrigation and Drainage Malaysia

Table 1. Simulation model in HEC-HMS

\begin{tabular}{lll}
\hline No & Model & Method \\
\hline 1 & Precipitation & User hyetograph \\
2 & Volume runoff & Initial and constant rate \\
3 & Transform method & SCS unit hydrograph \\
4 & Base flow & Recession \\
\hline
\end{tabular}

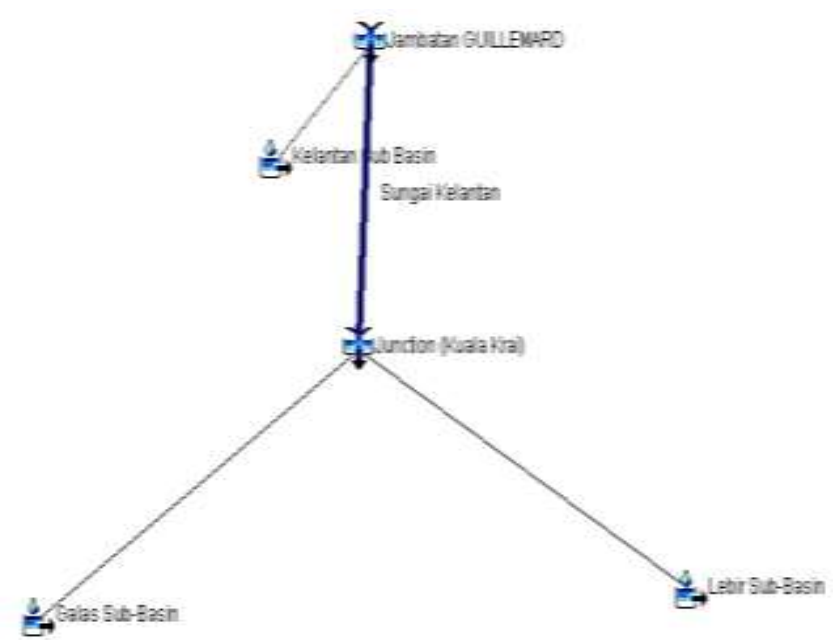

Figure 3. Catchment area in Kelantan

\section{RESULT AND DISCUSSION}

\subsection{Thiessen Polygon}

There is 21 rainfall station located in the catchment. The Thiessen Polygon analysis is analyzed based on three sub-catchments in Kelantan which are Lebir, Galas and $\mathrm{Sg}$ Kelantan sub-catchment. The mean hourly rainfall in the sub-catchment is calculated by multiplying it with the weighting coefficient of Thiessen. Table 2, 3 and 4 show the weight coefficient of Thiessen Polygon based on the 3 sub-catchment area in Kelantan. While, Figure 4, 5 and 6 shows the result of the mean hourly rainfall as an input into HEC-HMS.

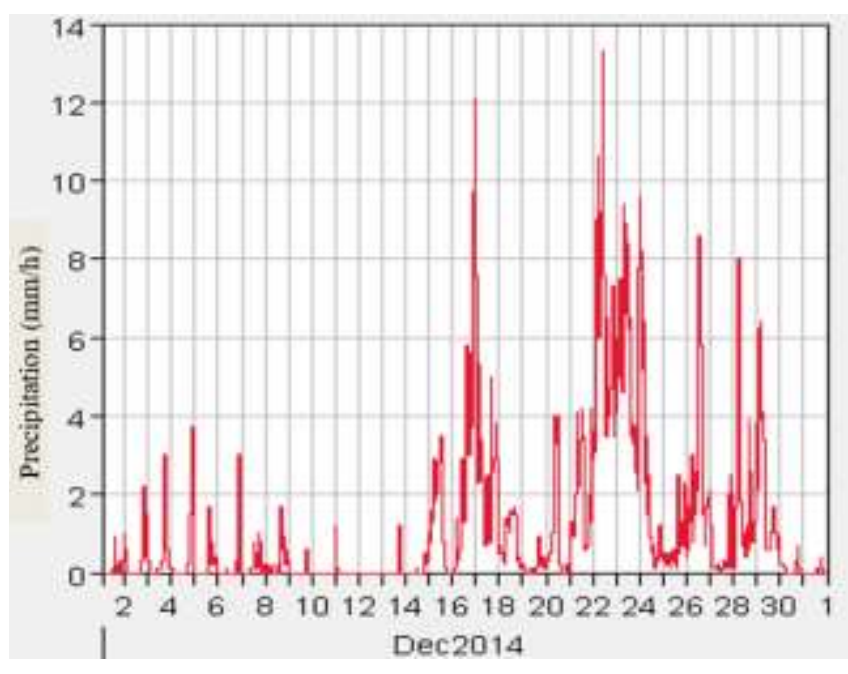

Figure 4. Mean hourly rainfall in Galas sub-catchment

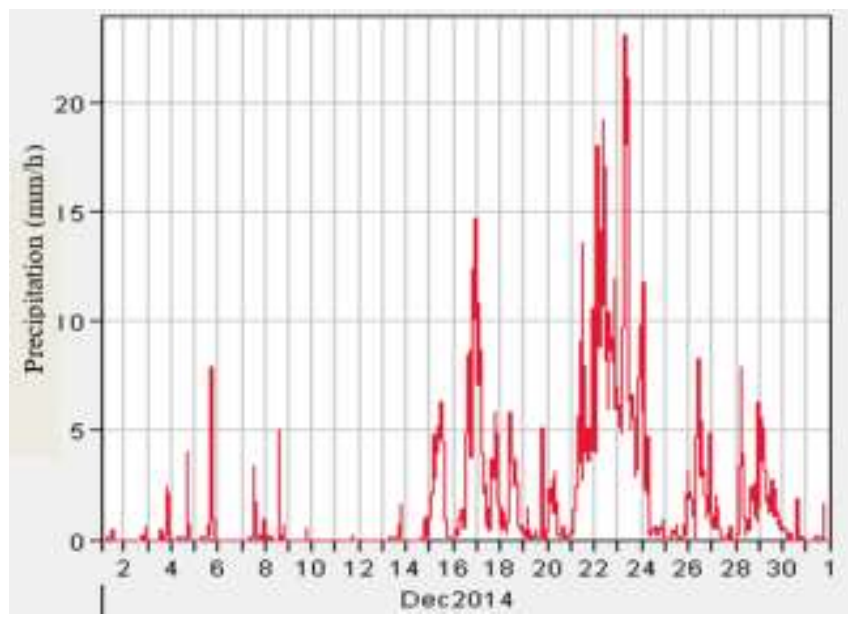

Figure 5. Mean hourly rainfall in Lebir sub-Catchment.

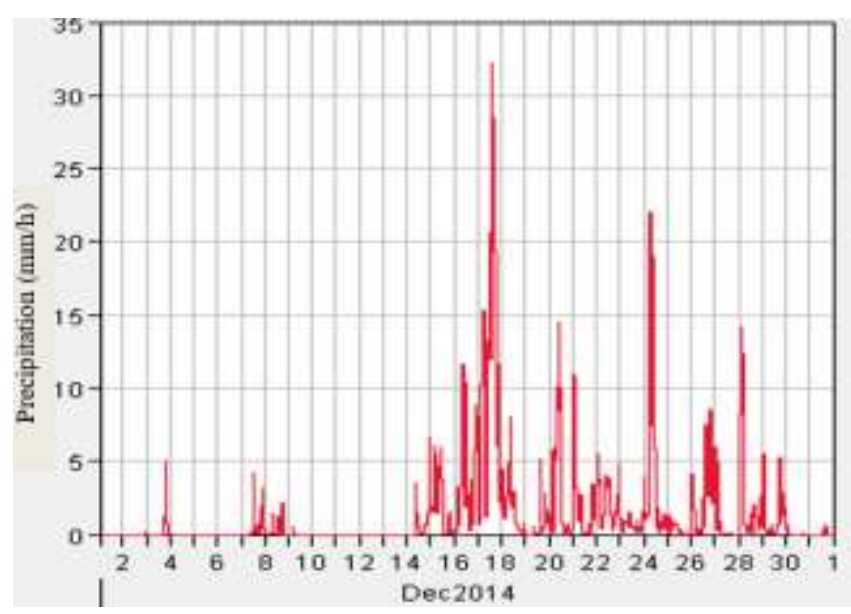

Figure 5. Mean hourly rainfall in Sg. Kelantan subcatchment 
Table 2. Weighting coefficient in Lebir sub-catchment

\begin{tabular}{lllll}
\hline $\mathrm{y}$ & $\mathrm{x}$ & Station Name & Area of polygon $(\mathrm{km} 2)$ & Weighting Coefficient \\
\hline 4.7653 & 102.1736111 & Upper Chiku & 517 & 0.1568568 \\
4.7569 & 102.6555556 & Gunung Gagau & 369 & 0.1119539 \\
4.9375 & 102.3527778 & Kg. Aring & 1205 & 0.3655947 \\
5.1458 & 102.0486111 & Balai Polis Bertam & 33 & 0.0100121 \\
5.3083 & 102.2750000 & Kg. Laloh & 947 & 0.287318 \\
5.5319 & 102.2027778 & Sek. Men. Teknik Kuala Krai & 225 & 0.0682646 \\
\hline \multicolumn{2}{l}{ Area of Catchment } & & 3,296 & 1 \\
\hline
\end{tabular}

Table 3. Weighting coefficient in Galas sub-catchment

\begin{tabular}{lllll}
\hline $\mathrm{y}$ & $\mathrm{x}$ & Station Name & Area of polygon $\left(\mathrm{km}^{2}\right)$ & Weighting Coefficient \\
\hline 4.6764 & 101.4847222 & Brook & 965 & 0.1218896 \\
4.7667 & 101.7569444 & Blau & 945 & 0.1193634 \\
4.7653 & 102.1736111 & Upper Chiku & 241 & 0.0304408 \\
4.8792 & 101.9694444 & Gua Musang & 819 & 0.1034483 \\
4.9375 & 102.3527778 & Kg. Aring & 92 & 0.0116206 \\
5.0986 & 101.7625000 & Gemala & 1096 & 0.1384363 \\
5.1458 & 102.0486111 & Balai Polis Bertam & 898 & 0.1134268 \\
5.2514 & 101.6625000 & Gob & 901 & 0.1138057 \\
5.3778 & 102.0152778 & Dabong & 814 & 0.1028167 \\
5.3083 & 102.2750000 & Kg. Laloh & 26 & 0.0032841 \\
5.5639 & 102.0083333 & Ulu Sekor (Ulu Sokor) & 311 & 0.0392826 \\
5.5319 & 102.2027778 & Sek. Men. Teknik Kuala Krai & 97 & 0.0122521 \\
5.7014 & 101.8388889 & Kg. Jeli & 705 & 0.0890489 \\
5.7806 & 101.9680556 & Kg. Durian Daun (Lawang) & 7 & 0.0008842 \\
\hline \multicolumn{2}{l}{ Area of Catchment } & & 7,917 & 1 \\
\hline
\end{tabular}

Table 4. Weighting coefficient in Sg. Kelantan sub-catchment

\begin{tabular}{llllc}
\hline $\mathrm{y}$ & $\mathrm{x}$ & Station Name & Area of polygon $\left(\mathrm{km}^{2}\right)$ & Weighting Coefficient \\
\hline 5.5639 & 102.0083333 & Ulu Sekor (Ulu Sokor) & 274 & 0.1747449 \\
5.5319 & 102.2027778 & Sek. Men. Teknik Kuala Krai & 466 & 0.2971939 \\
5.7806 & 101.9680556 & Kg. Durian Daun (Lawang) & 100 & 0.0637755 \\
5.7875 & 102.2194444 & Jps Machang & 546 & 0.3482143 \\
5.8444 & 102.0736111 & Bendang Nyior & 146 & 0.0931122 \\
5.8306 & 102.4152778 & Sg. Petai (Pasir Puteh) & 36 & 0.0229592 \\
\hline \multicolumn{2}{l}{ Area of Catchment } & & 1,568 & 1 \\
\hline
\end{tabular}

\subsection{Simulation Result}

HEC-HMS was applied to simulate the flood event in Kelantan on December 2014. The HEC-HMS result shows the hydrograph at Jambatan Guillemard has a good agreement compared to the observed data from Department of Irrigation and Drainage Malaysia.
Figure 6 shows the comparison hydrograph between HEC-HMS and observed data. The hydrograph shows the two peak wave of flood happened in December 2014. The first flood wave is smaller than the second wave which is $12,622 \mathrm{~m}^{3} / \mathrm{s}$ for the first wave and $18,575 \mathrm{~m}^{3} / \mathrm{s}$. Table 5 shows the calibration result generate by HEC-HMS. 


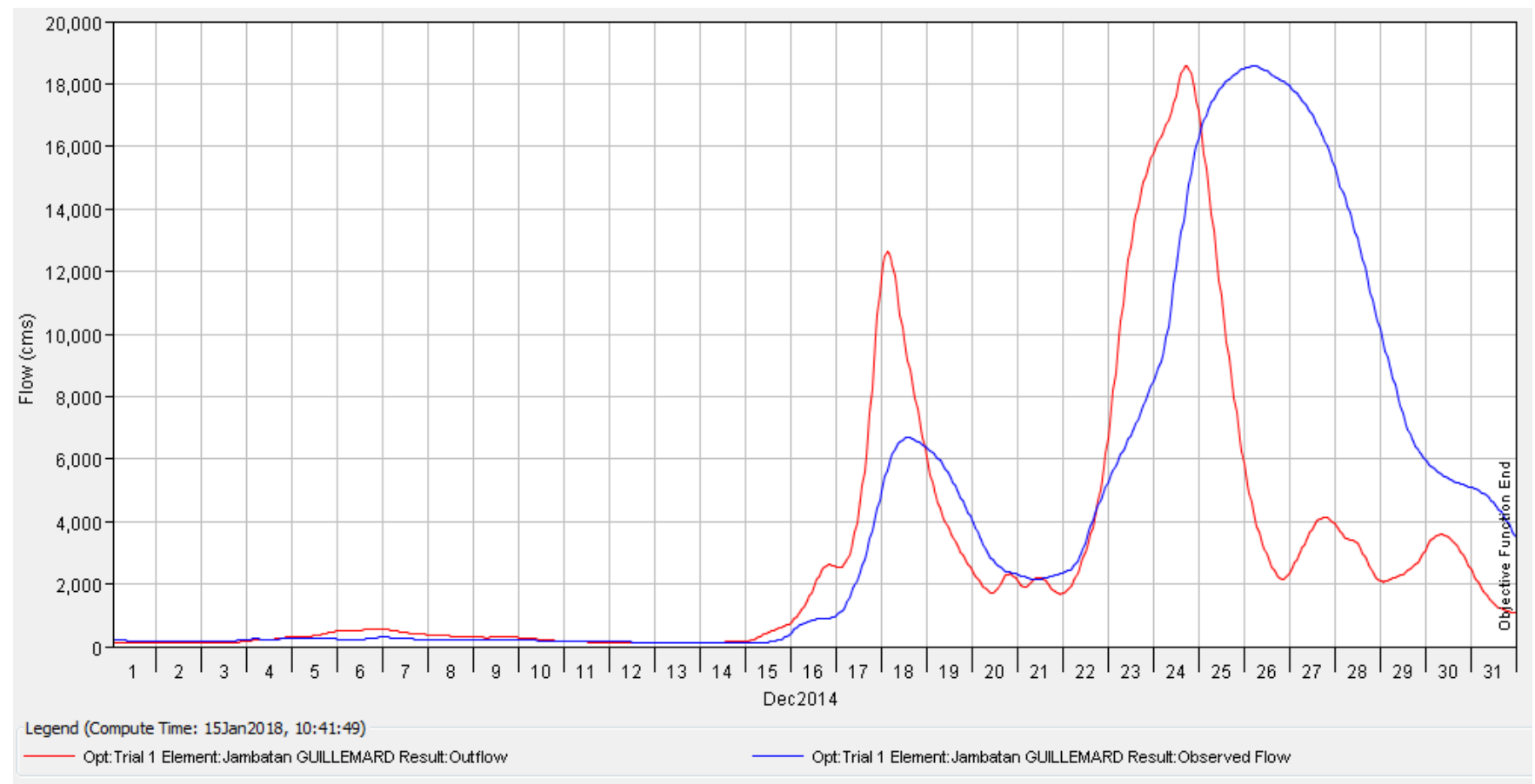

Figure 6. Comparison of flood hydrograph between result of HEC-HMS and observed data

Table 5. Calibration result generated by HEC-HMS.

\begin{tabular}{lllll}
\hline Measure & Simulated & Observed & Difference & Percent Difference \\
\hline Volume $(\mathrm{mm})$ & 608.87 & 871.19 & -262.32 & -30.11 \\
Peak Flow $\left(\mathrm{m}^{3} / \mathrm{s}\right)$ & $18,575.7$ & $18,576.4$ & -0.7 & 0 \\
\hline
\end{tabular}

The simulated result shows some slight difference magnitude compares to the observed data because of the recorded data that provided by Department of Irrigation and Drainage Malaysia is use water level gauge recorded. The Department of Irrigation and Drainage Malaysia was used Manning Equation in order to transform the water level to the discharge hydrograph so it might be some error happened during transformation analysis. The second reason is the water level recorded is not the best method/solution in order to get the discharge in the river. This is because at the certain level of water surface it might be inundated so the parameter of the area in Manning Equation is different due to the overflow from the capacity of the river. That is why the volume of the observed data is higher than the simulated result that running HECHMS. The last reason is the simulated result was analyze by using hydrology approach only. It is might be different discharge hydrograph if the simulation is running by hydraulic approach such as by using HECRAS whether the water level at Jambatan Guillemard is affected by backflow water inundation or not.

\section{CONCLUSIONS}

Kelantan suffered from extremely flood which occurred in December 2014. More than 19,544 people were affected by this flood disaster in the Kelantan River basin in Kelantan. HEC-HMS model was applied to simulate rainfall-runoff in Kelantan catchment. The objective here was to discuss whether or not the simulation model could provide useful information for the phenomenon.

The simulation showed good agreement in a maximum flooded area along Kelantan River. There is no doubt that model simulation involves large uncertainty. Therefore, we do not argue that such simulation alone can provide sufficient information for emergency response. Nevertheless, the model simulation performed here can provide additional information to help us to make the best decision for the mitigation in Kelantan catchment. The analysis of this catchment should include the hydraulic approach in order to get the better result for the further studies.

\section{REFERENCES}

Bernama, 2015. thesundaily. [Online]

Available at:

http://www.thesundaily.my/news/1270580

Department of Irrigation and Drainage Malaysia, 2014. Rainfall Station Data, DID Report. 
Yusop, Z., 2015. Damages during December 2014 Flood in Forensic Study of the Kelantan December 2014 Flood.

Romali, N.S., Yusop, Z., Sulaiman, M., Ismail, Z., 2018. Flood Risk Assessment: A Review of Flood Damage Estimation Model for Malaysia. Journal Teknologi, Vol 80, No 3, DOI:

https://doi.org/10.11113/jt.v80.11189
Fang, C. H., Chen, J. \& Xiao, K., 2016. A New Method to Quantify Breach Sizes for the Flood Risk Management of Concrete Arch Dams. Journal of Flood Risk Management. DOI:10.1111/jfr3.12240 
[this page is intentionally left blank] 